\title{
Accounting
}

\section{Pecking order, earnings management and capital structure}

\section{Novi Swandari Budiarso ${ }^{a^{*}}$ and Winston Pontoh ${ }^{\mathrm{a}}$}

${ }^{a}$ Economics and Business Faculty, Sam Ratulangi University, North Sulawesi, Indonesia

\begin{tabular}{l} 
C H R O N I C L E \\
\hline Article history: \\
Received: November 20, 2020 \\
Received in revised format: \\
January 30 2021 \\
Accepted: April 1, 2021 \\
Available online: \\
April 1, 2021 \\
\hline Keywords: \\
Capital structure \\
Agency problem \\
Earnings management
\end{tabular}

\section{Introduction}

The motivation of this study is based on research questions whether capital structure is determined by pecking order theory or agency problem. Those questions start from the point of work of Sunder \& Myers (1999) who suggest that profitable firms more prefer on internal fund rather than debt for financing the investments and Jensen (1986) who proposes the "control hypotheses" of debt creation in term to mitigate manager's opportunistic behavior to overinvest based on their own discretion. Based on those works, this study sets the main problems related to capital structure under circumstances that firms have two options to establish their capital structure whether to reduce or to increase the debt capacity. There are two main problems related to capital structure based on the setting of this study. The first is determining the source of funds for financing investments, and the second is solving the conflict between shareholders and managers. For the first problem, pecking order theory may explain firm capital structure in terms of financing investments. In perspective of pecking order theory, Myers (1984), and Myers (2001) suggest that firms should obtain more debt after they have insufficient retained earnings, thus, the larger profit implies lower debt. The studies of Sunder and Myers (1999), Chen (2004), Güner (2016), Rodrigues et al. (2017), and Lourenço and Oliveira (2017) show that firms first finance investments with earnings, followed by debt firm which imply that most of firms' capital structure can be explained by pecking order theory. The second common problem of firms is how to align the conflicting interests of shareholders and managers, often referred to as the agency problem. Most recent studies show that substantial efforts are made to align the interests of shareholders and managers. One approach to preventing the agency problem is to issue debt (and at once establish the capital structure) to control usage of funds by managers through discretionary actions, or earnings management (Jensen and Meckling, 1976; Jensen, 1986). Harris and Raviv (1991) explain that the conflict between stockholders and

* Corresponding author

E-mail address: novi.sbudiarso@unsrat.ac.id (N. S. Budiarso)

(C) 2021 by the authors; licensee Growing Science, Canada doi: $10.5267 /$ j.ac.2021.3.026 
managers arises since managers have less benefit from their profit enhancement activities, although they must bear the entire cost of those activities. Supporting Jensen and Meckling (1976), and Jensen (1986), the studies by Zamri et al. (2013), Abbadi et al. (2016), An et al. (2016), Sincerre et al. (2016), and Ilmas et al. (2018) show that issuing more debt is a control measure to prevent managers' discretionary.

Based on main problems then the objective of this study is to provide evidence about how firms establish their capital structure in relation to pecking order theory and the agency problem by controlling earnings management in the context of Indonesian firms. This study finds that pecking order theory determines the capital structure of most Indonesian firms with high debt, but not firms with lower debt. Moreover, the findings show that earnings management is not effective for motivating Indonesian firms to establish corporate governance which implies that agency problems are unable to explain the capital structure model in the context of Indonesian firms. The remainder of this paper proceeds as follows. Section 2 reviews existing literature. Section 3 explains the research method, while section 4 presents and discusses the results. Section 5 concludes the paper.

\section{Literature review}

There are several studies about the relationship of debt and profitability in context of pecking order theory. Titman and Wessels (1988) provide evidence that profitability has a negative effect on firms borrowing in circumstances of increased market value of equity. Sunder and Myers (1999) provide evidence that the pecking order model is normally adopted by mature firms when their profitability increases. The authors confirm that firms tend to reduce the use of debt for financing investment activities in this situation. Chen (2004) also proves that most Chinese firms prefer to use retained earnings before debt to finance their investments when they have higher earnings. In this case, Chen (2004) confirms that Chinese firms prefer to adopt the pecking order model. On those results, the findings of Sunder and Myers (1999), and Chen (2004) imply that most firms with increasing profitability will decrease their debt capacity as suggested by pecking order theory. Supporting the results of Sunder and Myers (1999), and Chen (2004), Güner (2016) reports similar behavior of Turkish firms concerning their preferences for use of retained earnings and debt. Moreover, Lourenço and Oliveira (2017) also offer evidence that Portuguese firms tend to reduce their debt capacity as their profits become stable, which implies those firms also prefer to use the pecking order model to establish their capital structure. Supporting pecking order theory, Adair and Adaskou (2015) confirm that French firms also prefer internal funding, which results in a tendency to reduce debt when profits increase. Rodrigues et al. (2017) confirm that the imperfect markets in Latin America lead most firms in those countries to use internal funding to establish their capital structure. This study hypothesizes that Indonesian firms with higher profitability will decrease debt. Therefore, this study proposes the following hypotheses:

\section{$\mathrm{H}_{1}$ : Profitability has a negative relationship with debt.}

Another factor that controls capital structure in context of pecking order theory is business risk. Kale et al. (1991) find that business risk (measured by coefficient of variation of standard deviation of cash flow) can have a negative or positive so-called "U shaped" relationship with debt capacity. Kale et al. (1991) provide evidence that a positive relationship exists between business risk and debt when the debt itself increases the value of the firm. Sunder and Myers (1999) convince that an increase in firm value because of the existence of debt, regardless of the cost of financial distress, is still consistent with pecking order theory. Booth et al. (2001) also confirm that if business risk (measured by standard deviation of return on assets) increases firm value, then it will have a positive relationship with debt choice. Cheng and Shiu (2007) propose that business risk (measured by industry dummy) will have a positive relationship with debt when firms have lower business risk, which enables them to obtain more debt. Masson et al. (2009) also provide evidence that business risk (measured by regression coefficient of time of return on assets model) has positive significant effect on debt when firms have lower business risk. Reversely, Jensen et al. (1992) show evidence that business risk (measured by standard deviation of ratio first difference of operating income to total assets) has a negative relationship with debt. Supporting the result of Jensen et al. (1992), Crutchley et al. (1999) also provides evidence that business risk (measured by standard deviation of first difference in net operating income to assets divided by mean net operating income to assets) and debt have negative relationships. This study hypothesizes that Indonesian firms with higher business risk will increase debt to get optimum firm value. Therefore, this study proposes the following hypotheses:

\section{$\mathrm{H}_{2}$ : Business risk has a positive relationship with debt.}

The relationship of debt and earnings management starts from the point by Jensen (1986) who suggests that in the context of agency theory, debt will play the role of a control mechanism to prevent managers from spending free cash at their discretion. Jensen (1986) called this the control hypotheses of debt. Lara et al. (2005) analogize the discretionary of managers as earnings management. Jones (1991) reports that earnings management exists when managers tend to use accounting accruals to reduce reported earnings. However, Jiraporn et al. (2008) prove that earnings management is not always bad, but can benefit firm value. Jones (1991), and Dechow et al. (1995) provide a model to detect the earnings management by estimating the total accruals 
which contains non-discretionary accruals and discretionary accruals. Jones (1991), and Dechow et al. (1995) refer discretionary accruals as earnings management. Zamri et al. (2013) find that Malaysian firms increase leverage to decrease earnings management by managers, which is consistent with the control hypotheses of debt. In their study of firms in 37 countries, including Indonesia, An et al. (2016) show that earnings management is positively associated with financial leverage, which implies firms that practice earnings management use higher debt to prevent managers' discretionary spending of the firm's free cash. Abbadi et al. (2016), Sincerre et al. (2016), and Ilmas et al. (2018) provide evidence that higher financial leverage increases the practice of earnings management, which implies that firms that suffer because of debt tend to engage in earnings management with the objective of maintaining creditors' perception that they are safe. Daniel et al. (2008) confirm that the measurement of non-discretionary accruals somehow relates to firm operations and measurement of discretionary accruals reflects manager's control. Lara et al. (2005) convinces that non-discretionary accruals represent conservatism in term to keep reliability of accounting information and discretionary accruals somehow "abuse" conservatism principle. Following the works of Jones (1991), Lara et al. (2005), and Daniel et al. (2008) this study also assumes that non-discretionary accruals (normal) reflects that the managers behave under objective of principals otherwise manager's opportunistic behavior could be reflected in discretionary accruals (abnormal). Under this assumption, this study hypothesizes that Indonesian firms practicing earnings management will increase debt, otherwise they will reduce debt capacity and therefore posits:

$\mathrm{H}_{3}$ : Non-discretionary accruals has a negative relationship with debt.

$\mathrm{H}_{4}$ : Discretionary accruals has a positive relationship with debt.

\section{Method}

This study takes 47 firms in the consumer goods industry that are listed on the Indonesia Stock Exchange (www.idx.co.id) during the period 2010 to 2017 as population. Sample firms that were selected were required to have publicly published audit reports during the study period and to have remained listed on the stock exchange during the period. The final sample of this study are 28 firms in the consumer goods industry after excluding delisting firms and new listing firms. Logistic regression is conducted to test the hypotheses, using the following models:

$$
\begin{aligned}
& D A R=\alpha+\beta_{1} R O A+\beta_{2} \text { BRisk }+\beta_{3} \text { N.Disc }+\varepsilon \\
& D A R=\alpha+\beta_{1} R O A+\beta_{2} \text { BRisk }+\beta_{3} \text { Disc }+\varepsilon \\
& \text { DAR }=\alpha+\beta_{1} R O A+\beta_{2} \text { BRisk }+\beta_{3} \text { N.Disc }+\beta_{4} \text { Disc }+\varepsilon
\end{aligned}
$$

The dependent variable in this study is financial leverage, calculated as the ratio of total debt over total assets (DAR). The variable is a dummy variable based on the median of $D A R$, and equals 1 if a firm has high debt and 0 otherwise. The independent variables and their measurements are as follows: (1) return on assets $(R O A)$ represents profitability and is measured by the ratio of net income to total assets; (2) business risk (BRisk) is the business risk of each firm. This study follows the procedure of Jensen et al. (1992), and Booth et al. (2001) to measure business risk by estimates the standard deviation of ratio of net income to total assets of each firm during the period 2010 until 2017. This study uses net income rather than earnings before interests and tax (first difference of operating income) under assumption that in accounting perspective, net income shall be reflected in retained earnings; (3) non-discretionary (NDisc) is sum of $\alpha_{i}\left(1 / A_{i t-l}\right)+\beta_{i}\left(\Delta R E V_{i t} / A_{i t-l}\right)+\beta_{i}\left(\Delta P P E_{i t} / A_{i t-l}\right)$ for each firm as suggested by Jones (1991). This variable refers to normal accruals when managers record accruals according to legal accounting standards; and (4) discretionary (Disc) is the standardized residual error estimate of the regressions for each firm as suggested by Jones (1991). This variable refers to abnormal accruals when managers record accruals at their own discretion. This study follows the Jones (1991) model to estimate NDisc and Disc, where the model of total accruals is as follows:

$$
\begin{aligned}
& T A_{i t} / A_{i t-1}=\alpha_{i}\left(1 / A_{i t-1}\right)+\beta_{i}\left(\Delta R E V_{i t} / A_{i t-1}\right)+\beta_{i}\left(\Delta P P E_{i t} / A_{i t-1}\right)+\varepsilon_{i t} \\
& T A_{t}=\left(\Delta \text { Current assets } t-\Delta \text { Cash }_{t}\right)-\left(\Delta \text { Current liabilities }_{t}-\text { Depreciation and amortization expense }_{t}\right)
\end{aligned}
$$

$T A_{i t}$ equals total accruals in year $t$ for firm $i ; \triangle R E V_{i t}$ is the difference between revenues in year $t$ and revenues in year $t-1 ; P P E_{i t}$ is the difference between the acquisition cost of property, plant, and equipment in year $t$ and the acquisition cost of property, plant, and equipment in year $t-1 ; \mathrm{A}_{\mathrm{it}-1}$ is total assets in year $t-1$ for firm $i ; \Delta$ Current assets is the difference between current assets in year $t$ and current assets in year $t-1 ; \Delta$ Cash is the difference between cash in year $t$ and cash in year $t-1$; and $\Delta$ Current liabilities is the difference between current liabilities in year $t$ and current liabilities in year $t-1$. Following Jones (1991), this study excludes from current liabilities taxes payable and the current portion of long-term debt included in current liabilities.

\section{Results}

Table 1 reports that firms with higher debt have better ROA than firms with lower debt, indicating firms with higher debt have better profitability; however, the means difference test shows that the difference is not significant. The results for Disc also 
confirm that discretionary accruals does not differ between firms with higher debt and those with lower debt. Table 1 reports that the mean of Disc for both firms with higher and lower debt are zero which indicate these firms have less earnings management (less abnormal accruals).

Table 1

Descriptive statistics

\begin{tabular}{lccccccc}
\hline \multirow{2}{*}{ Variables } & \multicolumn{3}{c}{ Firms with higher debt } & \multicolumn{2}{c}{ Firms with lower debt } & \multirow{2}{*}{ Difference } \\
\cline { 2 - 6 } & Min & Max & Mean & Min & Max & Mean & -0.03 \\
ROA & -0.21 & 0.67 & 0.11 & -0.03 & 0.42 & 0.13 & $0.02 * * *$ \\
BRisk & 0.02 & 0.13 & 0.06 & 0.01 & 0.07 & 0.04 & $-0.36^{* * *}$ \\
NDisc & -2.74 & 1.04 & -0.39 & -0.93 & 1.48 & -0.03 & 0.00 \\
Disc & -1.41 & 1.41 & 0.00 & -1.73 & 1.63 & 0.00 & 0.00 \\
\hline
\end{tabular}

Notes: This table reports descriptive statistics for firms with higher and lower debt. ROA is return on assets, measured by the ratio of net income over total assets. BRisk is business risk measured by the standard deviation of return on assets. NDisc is non-discretionary accruals, measured by the sum of $\alpha_{i}\left(1 / A_{i t}\right.$ $\left.{ }_{1}\right)+\beta_{\mathrm{i}}\left(\Delta \mathrm{REV} \mathrm{V}_{\mathrm{it}} / \mathrm{A}_{\mathrm{it}-1}\right)+\beta_{\mathrm{i}}\left(\Delta \mathrm{PPE}_{\mathrm{it}} / \mathrm{A}_{\mathrm{it}-1}\right)$ for each firm. Disc is discretionary accruals, measured by the standardized residual error estimate of regressions for each firm. ${ }^{* *}, * *$, and $*$ indicate statistical significance at $0.01,0.05$, and 0.10 levels, respectively.

Table 1 also shows that BRisk is higher for firms with more debt than firms with less debt, indicating high debt firms have more business risk; this difference is significant. Similar results of the means difference test for NDisc indicate that non-discretionary accruals (normal accruals) for firms with higher and lower debt is different, although the result for the mean shows that firms with higher debt have higher NDisc which indicate these firms tend to record accruals according to legal accounting standards.

\section{Discussion}

Table 2 reports that all models have good fit based on the chi-square test. Kleinbaum and Klein (2010) suggest that the logistic regression model has a good fit if its chi-square is insignificant. Table 2 also shows that ROA has a negative and significant relationship with debt in all models. Based on this result, $\mathrm{H} 1$ is supported, and the negative relationship between profitability and debt is consistent with the pecking order theory as suggested by Sunder and Myers (1999), Chen (2004), Adair and Adaskou (2015), Güner (2016), Lourenço and Oliveira (2017), and Rodrigues et al. (2017). This finding implies that firms with higher debt tend to reduce their debt capacity as their profits improve, while firms with less debt do not. Table 2 shows that BRisk has a positive and significant relationship with debt in all models, supporting H2. This result is consistent with the findings of Kale et al. (1991), Booth et al. (2001), Cheng and Shiu (2007), and Masson et al. (2009). Assuming that the existence of debt increases firm value, the findings of this study are consistent with pecking order theory as suggested by Sunder and Myers (1999). Also, this finding confirms the result in descriptive statistics and implies that firms with higher debt are riskier.

Table 2

Regression results

\begin{tabular}{lccc}
\hline \multirow{2}{*}{ Independent variables } & \multicolumn{3}{c}{ Model } \\
\cline { 2 - 4 } & 1 & 2 & 3 \\
\hline Intercept & -1.135 & -0.958 & -1.135 \\
ROA & $-4.763^{* * *}$ & $-4.766^{* * *}$ & $-4.767^{* * *}$ \\
BRisk & $33.577^{* * *}$ & $33.906^{* * *}$ & $33.585^{* * *}$ \\
NDisc & $-0.925^{* * *}$ & & $-0.925^{* * *}$ \\
Disc & & 0.019 & 0.018 \\
Chi-square & 209.033 & 214.040 & 209.039 \\
Pseudo R-Squared & 0.293 & 0.224 & 0.293 \\
\hline
\end{tabular}

Notes: This table reports logistic regression of firms with higher and lower debt. Dependent variable is calculated by ratio of total debt over total assets (DAR) and measured by dummy based on median of DAR, where 1 is firm with higher debt and 0 is vice versa. The reference category is firms with lower debt. ROA is return on assets, measured by the ratio of net income over total assets. BRisk is business risk measured by the standard deviation of return on assets. NDisc is non-discretionary accruals, measured by the sum of $\alpha_{\mathrm{i}}\left(1 / \mathrm{A}_{\mathrm{it}-1}\right)+\beta_{\mathrm{i}}\left(\Delta \mathrm{REV} \mathrm{V}_{\mathrm{it}} / \mathrm{A}_{\mathrm{it}-1}\right)+\beta_{\mathrm{i}}\left(\Delta \mathrm{PPE} \mathrm{i}_{\mathrm{it}} / \mathrm{A}_{\mathrm{it}-1}\right)$ for each firm. Disc is discretionary accruals, measured by the standardized residual error estimate of regressions for each firm. $* * * * *$, and * indicate statistical significance at $0.01,0.05$, and 0.10 levels, respectively.

Table 2 shows that the result of NDisc is negative and significant, so H3 is supported. Although this result is inconsistent with the findings of Jensen (1986), Zamri et al. (2013), An et al. (2016), Abbadi et al. (2016), Sincerre et al. (2016), and Ilmas et al. (2018) but seems it supports the works of Lara et al. (2005), and Daniel et al. (2008). This finding implies that firms with higher debt tend to have better governance, carefully choose debt in a manner consistent with their business risk and reduce necessary debt, as the descriptive statistics indicate that they have lower profitability, supporting the pecking order theory. H4 is not supported, as Table 2 indicates that Disc has an insignificant relationship with debt. Although the results show a positive coefficient, consistent with the context of the agency problem, this result implies that insiders in firms with higher debt do not 
make decisions based on random or unsystematic discretion. This finding proves that earnings management does not exist in those firms. Additionally, the pseudo R-squared in model 3 improves when NDisc and Disc enter the model together.

\subsection{Robustness test}

This study uses the asset growth variable for a robustness test as it also has a direct relationship with pecking order theory. This study measures assets growth (AG) as the difference between total assets in year $t$ and total assets in year $t-1$ divided by total assets in year $t-1$, as suggested by Fama and French (2001), Fairchild, Guney, and Thanatawee (2014), and Adair and Adaskou (2015). Table 3 reports that all regression models have good fit based on the chi-square test. The results of ROA, BRisk, NDisc, and Disc in models 1,2, and 3 are consistent with the results in Table 2. Based on these results, all models in this study are robust.

\section{Table 3}

Robustness test: pecking order, earnings management, and capital structure

\begin{tabular}{|c|c|c|c|}
\hline \multirow{2}{*}{ Independent variables } & \multicolumn{3}{|c|}{ Model } \\
\hline & 1 & 2 & 3 \\
\hline Intercept & -1.508 & -1.382 & -1.508 \\
\hline ROA & $-5.022 * * *$ & $-4.963 * * *$ & $-5.023 * * *$ \\
\hline BRisk & $34.667 * * *$ & $35.199 * * *$ & $34.667 * * *$ \\
\hline NDisc & $-0.916 * * *$ & & $-0.916 * * *$ \\
\hline Disc & & 0.008 & 0.001 \\
\hline $\mathrm{AG}$ & $2.762 * *$ & $2.861 * * *$ & $2.762 * * *$ \\
\hline Chi-square & 204.945 & 210.868 & 204.944 \\
\hline Pseudo R-Squared & 0.328 & 0.268 & 0.328 \\
\hline
\end{tabular}

Notes: This table reports robustness test of firms with higher and lower debt. Dependent variable is calculated by ratio of total debt over total assets (DAR) and measured by dummy based on median of DAR, where 1 is firm with higher debt and 0 is vice versa. The reference category is firms with lower debt. ROA is return on assets, measured by the ratio of net income over total assets. BRisk is business risk measured by the standard deviation of return on assets. $\mathrm{AG}$ is asset growth, measured by the difference in total assets in year $\mathrm{t}$ and total assets in year $\mathrm{t}-1$ divided by total assets in year $\mathrm{t}-1$. NDisc is non-discretionary accruals, measured by the sum of $\alpha_{i}\left(1 / A_{i t-1}\right)+\beta_{i}\left(\Delta R E V_{i t} / A_{i t-1}\right)+\beta_{i}\left(\Delta P P E_{i t} / A_{i t-1}\right)$ for each firm. Disc is discretionary accruals, measured by the standardized residual error estimate of regressions for each firm. $*^{* *},{ }^{* *}$, and $*$ indicate statistical significance at $0.01,0.05$, and 0.10 levels, respectively.

\section{Conclusion and limitations}

The basic question of this study is whether capital structure is determined by pecking order theory or agency problem. Most studies suggest that firms increase or decrease their debt capacity according to pecking order theory or agency problem. Based on these circumstances then the study sets the main problems related to capital structure in the context of Indonesian firms. The first problem is determining the source of funds for financing investments based on pecking order theory, and the second problem is solving the conflict between shareholders and managers based on agency problems by controlling earnings management. This study limits the sample to the consumer goods industry since this industry attracts more investors in the capital market. This study finds that pecking order theory determines the capital structure of most Indonesian firms with high debt but not those with lower debt. Moreover, after controlling the earnings management, this study finds that agency problems are unable to explain the capital structure model in the context of Indonesian firms in the consumer goods industry. On those findings, this study implies that earnings management is not effective for motivating Indonesian firms to establish corporate governance. There are some limitations of this study: (1) this study takes the sample only for consumer goods industry, then it is very suggested for further studies to extend the sample to other industries in context of Indonesian firms or international firms; (2) this study focuses only for profitability, business risk, and earnings management variables to confirm both of theories, then it is very suggested for further studies to broaden other variables to confirm these theories, such as tangibility, income tax expense, and dividends, to observe how capital structures are formed.

\section{References}

Abbadi, S. S. Hijazi, Q. F. \& Al-Rahahleh, A. S. (2016). Corporate governance quality and earnings management: Evidence from Jordan. Australasian Accounting, Business and Finance Journal, 10(2), 54-75. https://doi.org/10.14453/aabfj.v10i2.4

Adair, P., \& Adaskou, M. (2015). Trade-off theory vs. pecking order theory and the determinants of corporate leverage: Evidence from a panel data analysis upon French SMEs (2002-2010). Cogent Economics \& Finance, 3(1), 1-12. http://dx.doi.org/10.1080/23322039.2015.1006477

An, Z., Li, D., \& Yu, J. (2016). Earnings management, capital structure, and the role of institutional environments. Journal of Banking \& Finance, 68, 131-152. http://dx.doi.org/10.1016/i.jbankfin.2016.02.007

Booth, L., Aivazian, V., Kunt, A. D., \& Maksimovic, V. (2001). Capital structures in developing countries. The Journal of Finance, 56(1), 87-130. https://doi.org/10.1111/0022-1082.00320

Chen, J. J. (2004). Determinants of capital structure of Chinese-listed companies. Journal of Business Research, 57(12), 1341-1351. https://doi.org/10.1016/S0148-2963(03)00070-5 
Cheng, S. R., \& Shiu, C. Y. (2007). Investor protection and capital structure: International evidence. Journal of Multinational Financial Management, 17(1), 30-44. https://doi.org/10.1016/j.mulfin.2006.03.002

Crutchley, C. E., Jensen, M. R.H., Jahera Jr., J. S., Raymond, J. E. (1999). Agency problems and the simultaneity of financial decision making: The role of institutional ownership. International Review of Financial Analysis, 8(2), $177-197$. https://doi.org/10.1016/S1057-5219(99)00011-3

Daniel, N. D., Denis, D. J., \& Naveen, L. (2008). Do firms manage earnings to meet dividend thresholds? Journal of Accounting and Economics, 45(1), 2-26. https://doi.org/10.1016/j.jacceco.2007.11.002

Dechow, P. M., Sloan, R. G., \& Sweeney, A. P. (1995). Detecting earnings management. The Accounting Review, 70(2), $193-225$. https://www.jstor.org/stable/248303

Fairchild, R., Guney, Y., \& Thanatawee, Y. (2014). Corporate dividend policy in Thailand: Theory and evidence. International Review of Financial Analysis, 31, 129-151. https://doi.org/10.1016/j.irfa.2013.10.006

Fama, E. F., \& French, K. R. (2001). Disappearing dividends: changing firm characteristics or lower propensity to pay? Journal of Financial Economics, 60(1), 3-43. https://doi.org/10.1016/S0304-405X(01)00038-1

Güner, A. (2016). The determinants of capital structure decisions: New evidence from Turkish companies. Procedia Economics and Finance, 38, 84-89. http://dx.doi.org/10.1016/S2212-5671(16)30180-0

Harris, M., \& Raviv, A. (1991). The theory of capital structure. The Journal of Finance, 46(1), 297-355. https://doi.org/10.1111/j.1540$\underline{6261.1991 . t b 03753 . \mathrm{x}}$

Ilmas, F., Tahir, S., \& Asrar-ul-Haq, M. (2018). Ownership structure and debt structure as determinants of discretionary accruals: An empirical study of Pakistan. Cogent Economics \& Finance, 6(1), 1-27. https://doi.org/10.1080/23322039.2018.1439254

Jensen, G. R., Solberg, D. P., \& Zorn, T. S. (1992). Simultaneous determination of insider ownership, debt, and dividend policies. Journal of Financial and Quantitative Analysis, 27(2), 247-263. http://dx.doi.org/10.2307/2331370

Jensen, M. C. (1986). Agency costs of free cash flow, corporate finance, and takeovers. American Economic Review, 76(2), $323-329$. http://www.jstor.org/stable/1818789

Jensen, M. C., \& Meckling, W. H. (1976). Theory of the firm: Managerial behavior, agency costs and ownership structure. Journal of Financial Economics, 3(4), 305-360. https://doi.org/10.1016/0304-405X(76)90026-X

Jiraporn, P., Miller, G. A., Yoon, S. S., \& Kim, Y. S. (2008). Is earnings management opportunistic or beneficial? An agency theory perspective. International Review of Financial Analysis, 17, 622-634. https://doi.org/10.1016/i.irfa.2006.10.005

Jones, J. J. (1991). Earnings management during import relief investigations. Journal of Accounting Research, 29(2), 193-228. https://doi.org/10.2307/2491047

Kale, R. K., Noe, T. H., \& Ramirez, G. G. (1991). The effect of business risk on corporate capital structure: Theory and evidence. The Journal of Finance, 46(5), 1693-1715. https://doi.org/10.1111/j.1540-6261.1991.tb04640.x

Kleinbaum, D. G., \& Klein, M. (2010). Logistic regression: A self-learning text. $3^{\text {rd }}$ Edition. New York: Springer. https://doi.org/10.1007/978-1-4419-1742-3

Lara, J. M. G., Osma, B. G., \& Mora, A. (2005). The effect of earnings management on the asymmetric timeliness of earnings. Journal of Business Finance \& Accounting, 32, 691-726. https://doi.org/10.1111/j.0306-686X.2005.00610.x

Lourenço, A. J. S. M., \& Oliveira, E. C. (2017). Determinants of debt: Empirical evidence on firms in the district of Santarém in Portugal. Contaduría y Administración, 62, 625-643. http://dx.doi.org/10.1016/j.cya.2016.06.010

Masson, R., Tookes, H., \& Um, T. (2009). Firm diversification and equilibrium risk pooling: The Korean financial crisis as a natural experiment. Emerging Markets Review, 10(1), 1-22. https://doi.org/10.1016/j.ememar.2008.11.001

Myers, S. C. (2001). Capital structure. The Journal of Economic Perspectives, 15(2), 81-102. https://doi.org/10.1257/jep.15.2.81

Myers, S. C. (1984). The capital structure puzzle. The Journal of Finance, 39(3), 575-592. https://doi.org/10.1111/j.15406261.1984.tb03646.X

Rodrigues, S. V., de Moura, H. J., Santos, D. F. L., \& Sobreiro, V. A. (2017). Capital structure management differences in Latin American and US firms after 2008 crisis. Journal of Economics, Finance and Administrative Science, 22(42), 51-74. https://doi.org/10.1108/JEFAS-01-2017-0008

Sincerre, B. P., Sampaio, J. O., Rubens, F., \& Santos, J. O. D. (2016). Debt issues and earnings management. Revista Contabilidade \& Finanças, 27(72), 291-305. https://dx.doi.org/10.1590/1808-057x201601660

Sunder, L. S., \& Myers, S. C. (1999). Testing static tradeoff against pecking order models of capital structure. Journal of Financial Economics, 51(2), 219-244. https://doi.org/10.1016/S0304-405X(98)00051-8

Titman, S., \& Wessels, R. (1988), The determinants of capital structure choice. The Journal of Finance, 43(1), 1-19. https://doi.org/10.1111/j.1540-6261.1988.tb02585.x

Zamri, N., Rahman, R. A., \& Isa, N. S. M. (2013). The impact of leverage on real earnings management. Procedia Economics and Finance, 7, 86-95. http://dx.doi.org/10.1016/S2212-5671(13)00222-0

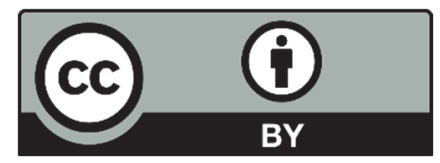

(C) 2021 by the authors; licensee Growing Science, Canada. This is an open access article distributed under the terms and conditions of the Creative Commons Attribution (CC-BY) license (http://creativecommons.org/licenses/by/4.0/). 